\title{
Pehmeät kvalifikaatiot sosiaali- ja terveysalan työssä ja ammatillisessa koulutuksessa
}

Jari Metsämuuronen

Monissa tehtävissä tarvitaan taitoja, jotka ovat "sosiaalisesti vaiettuja" ja joita ei tunnusteta ammattitaidon osaksi: kykyä vaikuttaa toisiin, innostuneisuutta, innostavuutta, yhteistyökykyä, kommunikointi- ja ihmissuhdetaitoja, tahdikkuutta, diplomatiaa, monitaitoisuutta, vastuun kantoa organisaation virheistä, tunteiden mukanaoloa, tai kykyä ohjata, kouluttaa ja perehdyttää muita. Kaikkea tällaista "yliammatillista osaamista" tarvitaan ennen muuta ihmistyössä.

Yhteiskunnan muuttuessa työ on muuttunut ja muuttuu. Myös työntekijät muuttuvat ja muuttavat työtään. Pelkästään se, että tietoa tuotetaan eksponentiaalisen kiihtyvästi, asettaa työntekijöille huikeita osaamistarpeita. Heidän tulee hahmottaa ja hallita edes osa vastaan tulevasta informaatiosta. Väärälä puhuukin "selviytymisen kvalifikaatioista“ ja "elämän hallinnan kvalifikaatioista" kuvatessaan ihmisten selviytymistä monimutkaisilla työmarkkinoilla. Peltonen käyttää termiä "henkiinjäämisperiaatteet" samantyyppisistä asioista (Väärälä 1996, 16 ja 1998, 32, Peltonen 1993, 145).
KVALIFIKAATIOT JA

\section{OSAAMINEN}

Kun työ muuttuu, muuttuvat myös työssä tarvittavat tai edellytettävät suoriutumisvaatimukset, joita nimitetään kvalifikaatiovaatimuksiksi (Taalas 1993, 170-172, Taalas 1995a, 8, Haltia \& Kivinen 1995,15, Räisänen 1998, 11). Käytän jatkossa suomenkielistä sanaa OSAAMINEN laajasti tarkoittamaan taitoja, kykyjä ja ominaisuuksia, joita ammattilainen tarvitsee suoriutuakseen työstä. Vastaavasti OSAAMISTARVE-sanalla tarkoitan niitä vaatimuksia tai edellytyksiä, joita työnte- 
kijältä edellytetään. Räisänen esittää, että taidot ovat vain osa ammatillista osaamista: ammatillinen osaaminen on kirjallisuudessa ymmärretty taitojen hallinnan lisäksi myös toimintojen hallinnaksi, pätevyydeksi ja kvalifikaatioksi (Räisänen 1998, 10-15).

$\mathrm{K}$ VALIFIKAATIOkäsitteistön sekavuus on silmiin(1997, 23, 45 ja 1998b, 86) äskettäin. Termejä käytetään osittain korvaamaan toisiaan (Jaakkola 1995, 115). Toisinaan termin kvalifikaatio sijaan olisi voitu puhua TAIDOSTA (Kuusi 1996, 87), osaamisesta (Mäkelä 1995, 128) tai vaLMIUKSISTA (Turtiainen 1997, 17), mutta kirjoittajat ovat halunneet käyttää termiä kvalifikaatio.

Taalaksen tapa jäsentää käsitteitä kvalifikaatio ja ammattitaito on mielestäni onnistunut (Taalas 1993, 1995a). Hänen esittämäänsä kompassimallia mukaellen (Pelttari 1997, 45 ja 1998b, 93) mainitut käsitteet voidaan jäsentää seuraavasti (kuva 1): Kvalifikaatiovaatimukset ovat niitä vaatimuksia, joita työ tai työnantaja edellyttävät työntekijältä. Kvalifikaatio ja kompetenssi puolestaan ovat sitä, millä työntekijät vastaavat työnantajan tai työn asettamiin haasteisiin.

\section{Perinteiset kvalifikatio- luokitukset ja pehmeä osaminen}

Kvalifikaatiot voidaan luokitella monella eri tavalla. Perinteinen ja usein esitetty tapa luokitella kvalifikaatiot on jako tuotannollisiin, normatiivisiin ja innovatiivisiin kvalifikaatioihin (näin

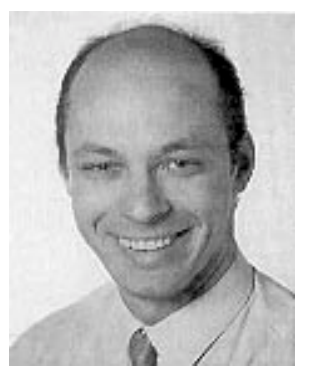

Jari Metsämuuronen

esimerkiksi Vuorinen 1988) tai jako teknisiin, motivaatio-, mukautumis-, sosiokulttuurisiin ja innovatiivisiin kvalifikaatioihin (mm. Ollus ym. 1990, 138-139, Taalas 1995, 107-108, Väärälä 1995a, 1995b, Pelttari 1997, Räisänen 1998). Lisäksi käytettyjä jakoperusteita ovat olleet jako sensomotorisiin, kognitiivisiin ja motivaatiokvalifikaatioihin (Toikka 1984), perus-, tuottaviin ja intensiteettikvalifikaatioihin (Kivinen ym. 1993) sekä ydin- ja reunakvalifikaatioihin (Helakorpi 1995).

Vaikka perinteinen itäsaksalaisen todellisuuden pohjalta syntynyt luokittelu onkin syntynyt teollisen yhteiskunnan tarpeisiin eikä sillä välttämättä ole enää relevanssia uusissa informaatio- tai tietoyhteiskuntakehityksen vaiheissa, olen silti valinnut sen lähtökohdaksi pohtiessani kvalifikaatioita nimenomaan ammatillisen koulutuksen ja erityisesti sosiaali- ja terveysalan osaamisen yhteydessä. Ammatillisia tietoja, taitoja ja pätevyyksiä Väärälä (1995b, 48) nimittää tuotannollisteknisiksi kvalifikaatioiksi. Nämä kvalifikaatiot ovat oleellisia työn suorittamiseksi hyvin. Tuotannollis-teknisiin kvalifikaatioihin liittyy oleel-

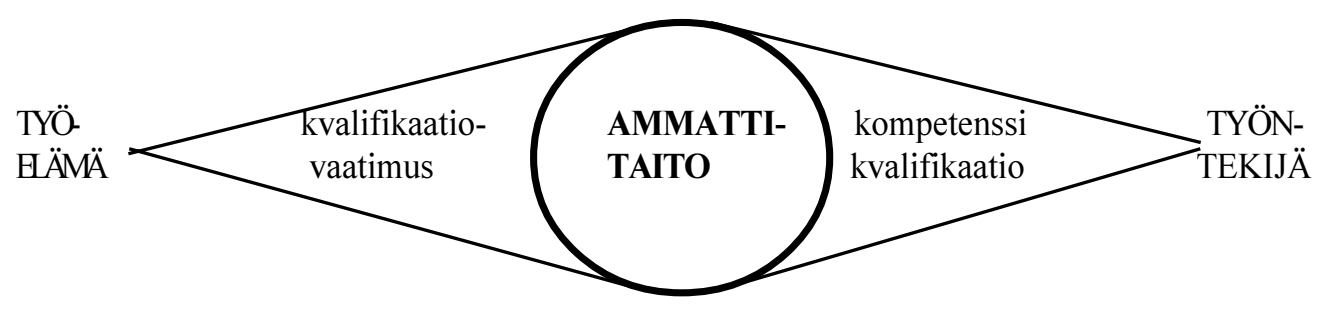

Kuva 1. Käsitteet kvalifikaatio, kvalifikaatiovaatimus, kompetenssi ja ammattitaito Pelttarin (1997, 1998b) mukaan (mukaellen Taalas 1993, 170, Taalas 1995a, 20) 
lisesti muitakin kvalifikaatioita: motivaatiokvalifikaatiot (mm. sitoutuminen, itseohjautuminen, reflektio ja lojaliteetti), mukautumiskvalifikaatiot (mm. työaikaan, -tahtiin ja -kuriin sopeutuminen, tunnollisuus, nopeus), sosio-kulttuuriset kvalifikaatiot (mm. tiimityö- ja verkostoitumistaidot, kommunikointi, vuorovaikutus) sekä innovatiiviset kvalifikaatiot (mm. muutosten havainnointi, työn analysointi, jatkuva oppiminen, ammattitaidon kehittäminen). Mainitut kvalifikaatiot ovat Väärälän ajattelussa aina toisiinsa suhteessa.

Kirsti Kivinen (1991, 1994, 1998) on toisaalta Suomessa nostanut esiin termin "Ä̈ÄETÖN AMMATTITAITO“. Hän tarkoittaa sillä sellaisia työssä tarvittavia taitoja, jotka ilmenevät käytännöllisenä tai toiminnallisena tietona, ovat osa työn kokonaishallintaa, mutta eivät välttämättä ole tiedostettuja. Tieto on mahdollisesti tullut kokemuksen kautta ja sisäistynyt niin, ettei sitä tarvitse tietoisesti pohtia. Koska mainitunkaltainen äänetön ammattitaito on oleellista työn suorittamiseksi hyvin, sen osatekijöitä voitaisiin nimittää äänettömiksi kvalifikaatioiksi.

$\ddot{A}$ änettömät kvalifikaatiot voivat olla myös muulla tavalla näkymättömiä. Kivisen mukaan $(1998,76)$ ne voivat ilmetä kykynä vaikuttaa toisiin, innostuneisuutena, innostavuutena, rakentavana yhteistyökykynä, kommunikointi- ja ihmissuhdetaitoina, tahdikkuutena, diplomatiana, monitaitoisuutena, vastuun kantona organisaation virheistä, tai kykynä ohjata, kouluttaa ja perehdyttää muita. Ihanainen tuo keskusteluun mukaan tunteet, aidon vuorovaikutuksen ja kanssakäymisen osana ammattitaitoa (Ihanainen 1995, 87). "Äänettömyys" tässä yhteydessä tarkoittanee sitä, että kyseisiä ominaisuuksia ei aina tule ajatelleeksi ammattitaidon osatekijöiksi. Kivinen sanookin, että mainitut taidot eivät välttämättä ole perinteisiä äänettömiä taitoja, vaan "sosiaalisesti vaiettuja" taitoja, taitoja, joita ei tunnusteta ammattitaidon osaksi (Kivinen 1998, 76). Mikäli kyseiset "pehmeät" ammattitaidon osatekijät tiedostetaan ja tunnustetaan kvalifikaatiotekijöiksi, niitä voitaisiin nimittää esimerkiksi pehmeiksi kvalifikaatioiksi.
$\mathrm{N}$ äyttää siis siltä, että vaikka Kivinen ei sitä suoraan sanokaan, äänettömiä taitoja on ainakin kahdenlaisia. Toisaalta äänettömät taidot sisältävät itse työn suorittamiseen liittyviä automatisoituneita tietoja ja taitoja. Toisaalta äänettöminä taitoina pidetään sellaisia persoonallisia ominaisuuksia, jotka ovat ainakin osittain opittavissa. Viimeksi mainitut persoonallisuuden piirteet voitaisiin nimetä sosiaaliseksi osaamiseksi tai motivaatiotekijöiksi, mikä on varsin lähellä Väärälän (1995b) ja Olluksen ym. (1990) pohdintoja.

\section{Perinteisen kvalifikaatio- luokituksen ja pehmeän osaamisen yhdistäminen?}

Yhteiskunnan muuttuessa työ asettaa uudenlaisia vaatimuksia työntekijöille. Näitä uusia osaamisen alueita Väärälä $(1998,29)$ nimittää "uusiksi kvalifikaatioiksi“: informaatioyhteiskunta vaatii toisenlaisia taitoja kuin teollisuusyhteiskunta. Silmiin pistävää uudemmissa suomalaisissa kvalifikaatiotutkimuksissa (ks. esim. Honkakoski 1995, 77-79, Hautamäki 1996, 33-35, Mannermaa 1996, 13, Kuusi 1996, 87, Schienstock ja Koski 1997, 64-67, Turtiainen 1997, 23, Kaivo-oja 1998, Korhonen 1998, 74-75, Pelttari 1998a, 72) on se, että alalla kuin alalla tarvitaan samantyyppisiä taitoja - eräänlaisia YLIAMMATILLISTA OSAAMISTA (Honkakoski 1995, 78-79).

$\mathrm{T}$ urtiainen (1997, 23) on huomannut, että 1990-luvun työssä osaamisen profiilissa korostuvat yhä selkeämmin työntekijän subjektiivisesti määräytyvät henkilökohtaiset ominaisuudet kuten itsensä hallinta, vuorovaikutustaidot, kommunikointikyky ja valmius siirtyä toimesta toiseen. Nykyisin työssä vaadittavaa osaamista saattaa perinteisen kvalifikaatioluokituksen sijasta paremmin hahmottaa Kaivo-ojan (1998) käyttämä jako YLEISOSAAMISEEN ja ASIAOSAAMISEEN tai Honkakosken (1995) jako yleisosaamiseen ja alalla tyypillisesti vaadittavaan osaamiseen. Yleisosaaminen tai reunaosaaminen olisi osaamista, jota tarvitaan alalla kuin alalla. Asiaosaaminen tai alalla tyypillisesti vaadittava osaaminen puolestaan olisi nimensä mukaisesti kullekin alalle tyypillistä erityisosaamista. 
Tuntuu houkuttelevalta ajatukselta yrittää yhdistää perinteinen kvalifikaatioluokitus, Kivisen ajatukset äänettömästä osaamisesta sekä asia/yleisosaamisajattelu. Voidaan ajatella, että perinteisen luokituksen "kovat" tuotannollis-tekniset kvalifikaatiot pitäisi täydentää niillä "pehmeillä“ äänettömillä kvalifikaatioilla, jotka ovat oleellisia työn suorittamiseksi hyvin. Äänettömät kvalifikaatiot voitaisiin tosin sisällyttää perinteisiin motivaatio-, mukautumis-, sosiaalis-kultturaalisiin ja innovatiivisiin kvalifikaatioihin. Ilmeisesti ne on sinne ajateltukin, mutta eivät tule julkituoduiksi. Toisaalta on myös mahdollista, että nämä taidot - kuten myös Väärälän (1998, 29) esittämät uudet kvalifikaatiot - eivät välttämättä olleet oleellisia, kun luokitusta kehiteltiin teollisuusyhteiskunnan tarpeisiin.

Erilaisten kvalifikaatioluokitusten osittain keinotekoista yhteyttä olen havainnollistanut kuvassa 2. Kuvan taustalla on ajatus siitä, että kun saksalaisesta perinteestä nousevat tuotannollistekniset kvalifikaatiot ovat olleet perustavaa laatua olevia työssä selviytymisen edellytyksiä, nykyyhteiskunnassa oleellisemmiksi kvalifikaatioiksi ovat saattaneet nousta yleiset hyvän työntekijän ominaisuudet. Toisin sanoen, joustava työpisteestä toiseen tai alalta toiselle siirtyminen edellyttää työntekijältä yliammatillisia ominaisuuksia kuten motivaatio-, mukautumis-, sosio-kulttuurisia ja innovatiivisia valmiuksia (Ellä 1998). Näitä yleisiä tai reunakvalifikaatioita saattaa olla

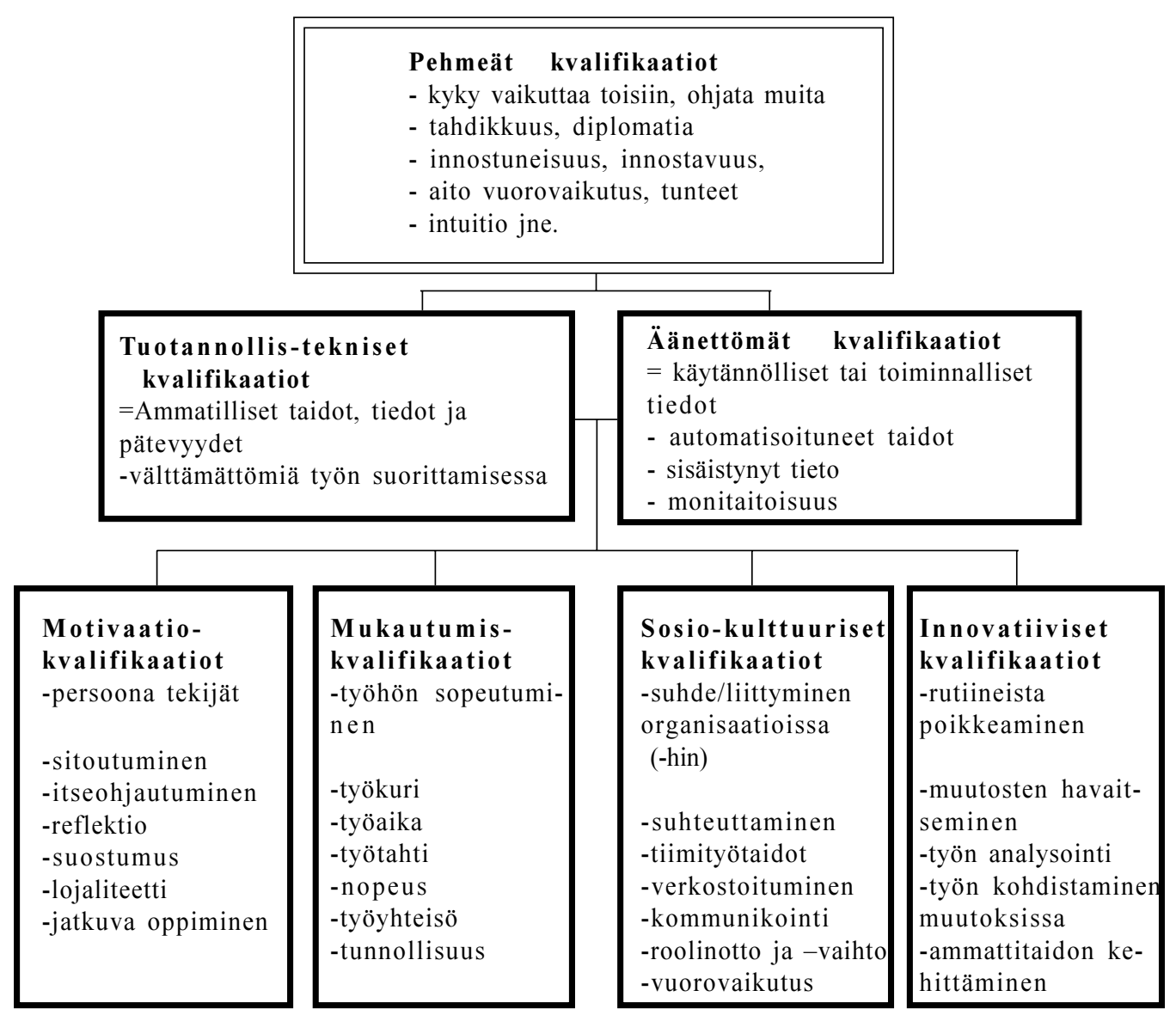

Kuva 2. Ammatillisen osaamisen osatekijöitä (mukaellen Vuorinen 1988, Ollus ym. 1990, Väärälä 1995a, 1995b, Kivinen 1991, 1994, 1998, Ihanainen 1996) 
muitakin tai ne saattaisi olla mahdollista jakaa jollain muullakin tavalla. Ehkä oleellisinta osaamista, joustavuutta ja muutosherkkyyttä kuvaavassa yhteiskunnan tilanteessa edustavat ns. metataidot: oppimiskyky, oppimaan oppiminen ja kyky analysoida omaa toimintaansa (Kivinen 1998, 79).

Y leiskvalifikaatiot eivät tietenkään riitä työssä suoriutumiseksi; tarvitaan kullekin alalle tyypillistä osaamista, jotta selviäisi työstä. Tässä mielessä tuotannollis-tekniset kvalifikaatiot laajasti ymmärrettynä kunkin alan tyypillisenä osaamisena yhdistettynä automatisoituneisiin taitoihin, äänettömiin kvalifikaatioihin, ovat oleellisia. Vaikka siis nykyisessäkin keskustelussa tärkeiksi kvalifikaatiovaatimuksiksi näyttävät kohoavan muut kuin tuotannollis-tekniset kvalifikaatiot, on Mäkisen $(1998,85)$ mukaan oleellista, että asiakkaalla edelleenkin on parturista tullessaan korvat tallella. Pelkällä ydinkvalifikaatioiden eikä myöskään yleiskvalifikaatioiden hallinnalla ei pärjää muuttuvilla työmarkkinoilla; tarvitaan molempia.

Yleiskvalifikaatiot ovat oleellisia työntekijälle, jotta hän voisi kehittyä työssään ja kasvattaa ammattitaitojaan. Taitojen määrä vaihtelee työntekijöittäin. Voidaan poleemisesti esittää, että mikäli työntekijällä on vankat ammatilliset tiedot ja taidot ja niiden lisäksi hänellä on edes yhdellä motivaatio-, mukautumis-, sosiaalis-kultuuraalisen tai innovatiivisten kvalifikaatioiden alueella hyviä ominaisuuksia tai taitoja, hän on kullan arvoinen työnantajalle. Näin esimerkiksi työntekijä, jolla vankan taidon lisäksi on motivaatiokvalifikaatioihin kuuluvia ominaisuuksia hän on sitoutunut, lojaali työnantajalle, itseohjautunut ja kykenee itsereflektioon - hän on työnantajalleen aarre, vaikka hänellä olisi puutteita työaikaan sopeutumisessa, ei kykenisi tiimityöhön eikä hänellä olisi juurikaan kykyä poiketa rutiineista. Työnantajan haastava tehtävä olisi tällöin löytää työntekijälle juuri sellainen toimenkuva, joka hyödyntäisi työntekijästä juuri hänen vahvat puolensa organisaation palvelukseen. Mainittu työntekijä lienee kuitenkin harvinainen poikkeus, sillä esimerkiksi sosiaali- ja terveysalalla ei ilmeisestikään riitä se, että olisi vain yhdellä yleiskvalifikaatioiden alueella vahva. Nykyisessä työllisyystilanteessa vankan ammattitaidon omaavalle, mutta muuten kurjalle, joustamattomalle tai epäsosiaaliselle tyypille ei sosiaali- ja terveysalalla liene sijaa.

$\mathrm{K}$ olmantena "tasona" kuviossa on pehmeät ai emotionaalis-moraaliset kvalifikaatiot. Jotta voisi tehdä työnsä hyvin erityisesti sosiaali- ja terveysalalla, jossa toimitaan ihmisten parissa, on hyvällä työntekijällä oltava myös pehmeitä taitoja. Esimerkkinä voidaan kuvitella tilannetta todellisesta elämästä: Kaksi hoitajaa auttaa täsmälleen samanlaisessa asiassa vanhusta. Molemmat saattavat sanoa samoja sanoja ja tehdä teknisesti samat asiat oikein. Silti toisen äänessä on erilaista lämpöä ja hellyyttä kuin toisella, toisen kosketus on lämmin ja hyväilevä kun toisella se on tekninen ja kova. Asiakas aistii sen, milloin työntekijä on aidosti läsnä. Mitkä ovat ne taidot, jotka tekevät hyvästä, virheetöntä työtä tekevästä ammattilaisesta vielä erinomaisemman ammattilaisen, joka aikaansaa asiakkaassa tai kollegassa tuntemuksen lämpimästä ihmisestä? Se "jokin" saattaisi olla esimerkiksi pehmeät taidot.

\section{TUTKIMUKSEN TARKOITUS}

Koska pehmeä osaaminen on oleellinen osa hyvää ihmistyötä, voidaan kysyä, mitkä ovat pehmeitä taitoja tai tarvittavia pehmeitä ominaisuuksia. Asiasta ei ole paljonkaan empiirisiä havaintoja. Pehmeitä taitoja ei - kuten ei myöskään äänettömiä taitoja - ole helppo saada tutkittavaksi (Kivinen 1998, 78). Sosiaali- ja terveysalan työn tulevaisuuden osaamistarpeet - ennakointihankkeen (Metsämuuronen 1998) kiinnostuksen kohteena on ollut tulevaisuuden työssä tarvittava osaaminen. Eräänä pienenä, muttei vähäpätöisenä, yksityiskohtana tutkimuksessa selviää myös jotakin empiiristä äänettömistä ja pehmeistä osaamistarpeista: millaista saattaa olla pehmeä osaaminen, millaisia osaamistarpeita siihen sisältyy ja tarvitaanko pehmeitä taitoja sosiaali- ja terveysalan työssä nyt ja tulevaisuudessa. 


\section{MENETELMÄT}

\section{Tutkimusteknikka}

Tutkimus suoritettiin kahden kierroksen Delfitekniikalla (Metsämuuronen 1997). Delfi-tekniikan idea on se, että tutkija haastattelee asiantuntijoita ja kokoaa kunkin asiantuntijan vastaukset yhteen ja antaa kaikkien vastaukset uudelleen arvioitaviksi asiantuntijoille. Delfi-tekniikkaa kuvaavat termit anonyymisyys ja konsensus. Anonyymisyys tarkoittaa sitä, että asiantuntijat antavat mielipiteensä tietämättä toisten vastauksista: jokaisella on ikään kuin yksi ääni annettavana, eikä vahvojen persoonien vaikutus näy lopputuloksessa liikaa (Linstone \& Turoff 1975, Williams \& Webb 1994, 181). Konsensus tarkoittaa sitä, että ns. Delfi-kierroksilla pyritään löytämään yhteinen mielipide asiantuntijoiden joukosta. Moderneissa menetelmäkirjoissa täydellistä konsensusta ei pidetä suotavana (Turoff \& Hiltz 1996, 56). Ilmeisesti Kuusi on aivan oikeassa sanoessaan, että pyrkimys asiantuntijoiden yksimielisyyteen on usein väkinäistä ja saattaa johtaa tärkeän informaation katoamiseen (Kuusi 1993, 136).

Tutkimuksessa käytettiin jossain määrin perinteisestä Delfi-tekniikasta poikkeavaa tekniikkaa. Tutkimus aloitettiin normaaliin tapaan postikyselynä, jolloin mukaan saatiin noin 200 sosiaalialan ja terveysalan koulutuksen ja työelämän vastaajaa. Ensimmäisen kierroksen avoimet vastaukset analysoitiin sisällön analyysitekniikalla ja osaamistarpeista muodostettiin kvantitatiivisesti arvioitava mittari. Toisella kierroksella asiantuntijat saivat vastattavakseen lomakkeen, johon heidän piti arvottaa 6-portaisella Likert-asteikolla kukin osaamistarve sillä perusteella, tarvitaanko osaamista tänään ja tarvitaanko osaamista tulevaisuudessa. Näiden kahden numeron perusteella arvioitiin aluksi oliko kyseinen osio ns. "turha" osaamistarve, eli jotain sellaista, mitä asiantuntijat valtaosin eivät pitäneet tärkeänä osaamisena nyt eikä tulevaisuudessa. Toiseksi arvioitiin ns. muutosintensiteettiä, ts. sitä, kuinka paljon enemmän tai vähemmän kyseistä osaamista tarvitaan tulevaisuudessa kuin tänään
Toisella kierroksella asiantuntijat myös haastateltiin. Tällöin kiinnostuksena olivat ne perustelut, miksi jotain osaamista tarvitaan. Asiantuntijat perustelivat erityisesti ne osaamistarpeet, joiden suhteen tapahtui heidän mielestään muutosta tulevaisuuteen nähden.

\section{Tutkimuksen luotettavuus}

Tutkimuksen reliabiliteetin vuoksi asiantuntijat jaettiin kahteen erilliseen asiantuntijaraatiin: toisella kierroksella varsinaiseen asiantuntijaraatiin kuului työelämän ja koulutuksen edustajia $(n=41$, kato toisella kierroksella $4.7 \%$ ) ja kontrolliraatiin tutkimuslaitosten ja järjestöjen edustajia ( $\mathrm{n}=13$, kato toisella kierroksella $27.8 \%$ ).

Äänettömien ja pehmeiden osaamistarpeisiin luokiteltiin 10 osaamistarvetta: Esteettisyys, innostumisen ja innostamisen taito, intuition käyttö, toisten huomioiminen, ilmapiirin ja tunnelman luomisen taito, heittäytyminen ja irrotteleva työnote, ulospäin suuntautuneisuus, muiden aktivoinnin taito, motivoituneisuus työn tekemisessä sekä työn pehmeät ja äänettömät alueet ylipäänsä. Näiden osaamistarpeiden muodostaman mittarin Cronbachin alfa oli 0.80 , eli mittari oli kohtuullisen konsistentti.

Keskeiseksi ongelmaksi tutkimuksessa tulivat validiteettiongelmat, sillä useat osaamistarpeista olivat enemmän tai vähemmän monikäsitteisiä tai ainakin antoivat mahdollisuuden monenlaiseen ajatteluun. Selvästi monikäsitteiset tai epäselvät termit, kuten äänettömät ja pehmeät osaamistarpeet selitettiin haastattelun yhteydessä, jolloin asiantuntijoilla oli vielä mahdollisuus muuttaa numeroarvioitaan.

\section{PEHMEÄT OSAAMISTARPEET SOSIAALI- JA TERVEYSALALLA}

\section{Osaamistarpeiden muutosintensiteetin \\ luokittelu avulla}

Osaamistarpeen painoarvon ja muutosintensitee- 
tin avulla voidaan löytää kolmen tyyppisiä osaamistarpeita (kuva 3). Mikäli osaamistarpeen painoarvo on korkea, mutta muutosintensiteetti matala, osaamistarve on aidosti tulevaisuudessa tarvittavaa osaamista, mutta jota tarvitaan myös tänään. Näitä osaamistarpeita voidaan nimittää perusosaamiseksi. Mikäli osaamistarpeen painoarvo ja muutosintensiteetti ovat korkeita, voidaan sitä nimittää aidoksi tulevaisuudenosaamiseksi. Aidon tulevaisuudenosaamisen ja perusosaamisen välimaastoon sijoittuvat osaamistarpeet, joilla selvästi on painoarvoa tulevaisuudessa ja joiden muutosintensiteetti on kohtuullisen korkea, muttei niin korkea kuin aidolla tulevaisuudenosaamisella. Tätä osaamistarveryhmää nimitän potentiaaliseksi tulevaisuudenosaamiseksi, sillä näiden osaamistarpeiden muutosintensiteetin suhteen asiantuntijat yleensä eivät ole olleet yksimielisiä.

Tässä tutkimuksessa perusosaamisen ja "turhien" osaamistarpeiden väliseksi rajaksi määriteltiin osaamistarpeen painoarvon keskiarvo 5.0. Osaamistarpeen painoarvon maksimiarvo oli 6 , mikä

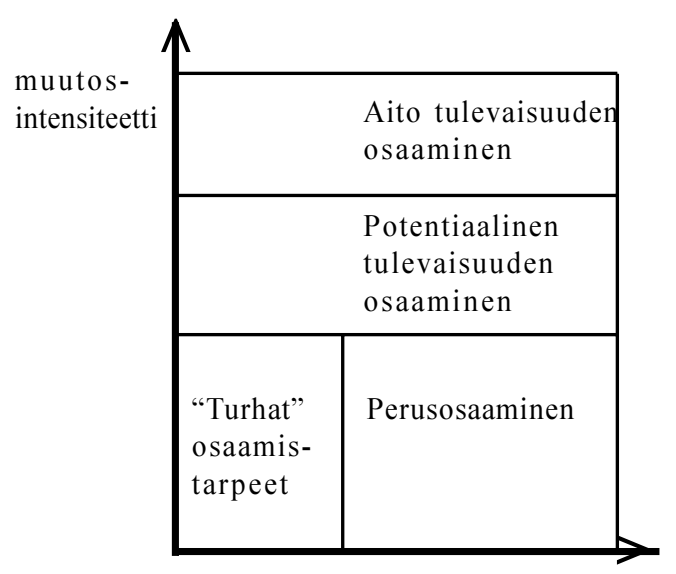

osaamistarpeen painoarvo

Kuva 3. Osaamistarpeiden ryhmittely painoarvon ja muutosintensiteetin avulla

tarkoitti, että asiantuntija oli täysin samaa mieltä väitteen kanssa siitä, että tätä osaamista tarvitaan tulevaisuudessa. Numeroarvo 5 tarkoitti, että asiantuntija oli melko pitkälti samaa mieltä siitä, että tätä osaamista tarvitaan tulevaisuudessa. Osaamistarpeen painoarvon keskiarvon nousu arvoon
5.0 tarkoittaa, että valtaosa asiantuntijoista on ollut täysin tai melko paljon samaa mieltä osaamistarpeen painoarvosta tulevaisuudessa.

\section{Pehmeä osaaminen}

Äänettömään ja pehmeään osaamiseen luettiin erinäisiä osaamistarpeita, joiden arveltiin saattavan olla eräänlaisia laatutekijöitä tulevaisuuden sosiaali- ja terveysalalla. Varsinaista äänetöntä osaamista osaamistarpeiden joukossa ei ole, mikäli pitäydytään perinteiseen käsitykseen, että äänetöntä osaamista ovat automatisoituneet taidot. Sen sijaan luetellut osaamistarpeet edustavat enemmänkin pehmeitä kvalifikaatioita. Kirjallisuudesta olisi ilmeisesti saatu lisää erilaisia pehmeitä osaamistarpeita, mutta tässä esille tulleiden lisäksi aineistossa ei esille tullut osaamistarpeita, joita ei voitu sijoittaa muihin osaamistarveluokkiin. Osa "pehmeisiin" osaamistarpeisiin mahdollisesti sopivista osaamistarpeista sijoittui mm. sosiaalisen osaamisen, moniammatillisuusosaamisen ja arvo-osaamisen luokkiin (ks. tarkemmin Metsämuuronen 1998).

$\ddot{\mathrm{A}}$ änettömien ja pehmeiden osaamistarpeiden joukossa perusosaamista olivat toisten huomioiminen (muutosintensiteetti 0.1), motivoituneisuus työn tekemisessä (0.2), ilmapiirin ja tunnelman luomisen taito (0.3), työn pehmeiden ja äänettömien alueiden hallinta sinänsä (0.3), innostumisen ja innostamisen taidot (0.3), intuition käyttö (0.3), esteettisyys (0.3) ja ulospäin suuntautuneisuus (0.3). Potentiaalista tulevaisuudenosaamista olivat heittäytyminen ja irrotteleva työnote $(0.5)$ ja muiden aktivoinnin taito $(0.5)$. Terveysalan edustajat painottivat lisäksi ilmapiirin ja tunnelman luomisen taitoa (0.4), motivoituneisuutta työn tekemisessä (0.4) ja työn pehmeiden ja äänettömien alueiden hallintaa sinällään $(0.4)$ potentiaalisena tulevaisuuden osaamisena. Aitoa tulevaisuudenosaamista ei äänettömien ja pehmeiden osaamistarpeiden joukossa, joskin terveysalan edustajat painottivat heittäytymistä ja irrottelevaa työnotetta (0.8) ja sosiaali- ja terveysalan edustajat muiden aktivoinnin taitoa (0.80) aitona tulevaisuudenosaamisena. 
Taulukko 1. Pehmeän osaamisen osaamistarpeet

\begin{tabular}{|c|c|c|c|}
\hline Osaamistarve & Painoarvo & $\begin{array}{l}\text { Muutos- } \\
\text { intensiteetti }\end{array}$ & Huomautuksia \\
\hline $\begin{array}{l}\text { Toisten huomioon- } \\
\text { ottaminen }\end{array}$ & 5,78 & 0,10 & $\begin{array}{l}\text { Painoarvojen välillä tilastollisesti } \\
\text { merkitsevä ero sosiaalialan }(5.4) \text { ja } \\
\text { terveysalan (5.9) välillä }(\mathrm{p}=0.017)\end{array}$ \\
\hline $\begin{array}{l}\text { Motivoituneisuus } \\
\text { työn tekemisessä }\end{array}$ & 5,78 & 0,20 & \\
\hline Intuition käyttö & 5,66 & 0,32 & \\
\hline $\begin{array}{l}\text { Muiden aktivoinnin } \\
\text { taito }\end{array}$ & 5,63 & 0,54 & \\
\hline Ulospäinsuuntautuneisuus & 5,59 & 0,34 & \\
\hline $\begin{array}{l}\text { Innostumisen ja } \\
\text { innostamisen taito }\end{array}$ & 5,55 & 0,29 & \\
\hline $\begin{array}{l}\text { Ilmapiirin ja tunnelman } \\
\text { luomisen taito } \\
\text { Työn pehmeät ja } \\
\text { äänettömät alueet }\end{array}$ & $\begin{array}{l}5,54 \\
5,41\end{array}$ & $\begin{array}{l}0,27 \\
0,27\end{array}$ & $\begin{array}{l}\text { Painoarvojen välillä tilastollisesti } \\
\text { merkitsevä ero sosiaalialan }(5.1) \\
\text { ja terveysalan }(5.7) \text { välillä }(\mathrm{p}=0.007)\end{array}$ \\
\hline $\begin{array}{l}\text { Esteettisyys } \\
\text { Heittäytyminen ja } \\
\text { irrotteleva työnote }\end{array}$ & 5,32 & 0,34 & $\begin{array}{l}\text { Painoarvojen välillä tilastollisesti } \\
\text { merkitsevä ero sosiaalialan }(5.0) \text { ja } \\
\text { terveysalan (5.7) välillä }(\mathrm{p}=0.027) \\
\text { Intensiteettien välillä tilastollisesti } \\
\text { merkitsevä ero sosiaalialan }(0.0) \text { ja } \\
\text { terveysalan }(0.4) \text { välillä }(\mathrm{p}=0.042)\end{array}$ \\
\hline
\end{tabular}

Pehmeät osaamistarpeet tulevaisuudenosaamisena perusteltiin sillä, että pehmeiden osaamistarpeiden hallinta on asiakkaan ja kollegoiden kannalta katsottuna laadukasta työskentelyä; esteettisyys, positiivisen ilmapiirin ja tunnelman luominen ja toisten huomioiminen työn käydessä yhä raskaammaksi resurssien vähyyden vuoksi saavat työn maistumaan mukavalta, mikä taas on asiakkaankin kannalta edullista. Samalla myös positiivisen asiakassuhteen luominen saattaa helpottua. Esteettisyyden sinällään sanottiin olevan parantavaa. Joskus ilman päästäminen pihalle hulluttelemalla, irrottelemalla tai ylipäänsä huumorilla saattaa laukaista jännitteitä ja edes- auttaa työviihtyvyyttä tai potilaan paranemista. Varsinaisen taitolajin asiasta tekee se, että ammattilaisen on ymmärrettävä, milloin näitä keinoja on hyvä käyttää.

Terveysalan ja sosiaali- ja terveysalan edustajien mielipiteet eivät eronneet toisistaan juuri lainkaan. Sen sijaan sosiaalialan ja terveysalan edustajien ilmaisemat osaamistarpeiden painoarvot erosivat toisistaan osittain huomattavastikin. Yleisesti ottaen sosiaalialan edustajat painottivat kaikkia äänettömiä ja pehmeitä taitoja osoittavia osaamistarpeita vähemmän kuin terveysalan edustajat. Terveysalan edustajat painottivat sosiaali- 
alan edustajia enemmän toisten huomioimista $(p=0.017)$, ilmapiirin ja tunnelman luomisen taitoa ( $\mathrm{p}=0.007)$ ja työn pehmeitä ja äänettömiä alueita sinänsä $(\mathrm{p}=0.027)$. Bonferroni-korjauksen jälkeenkin erot olivat tilastollisesti merkitseviä toisten huomioimisen $(\mathrm{p}=0.05)$ ja ilmapiirin ja tunnelman luomisen taidon $(p=0.021)$ suhteen. Sosiaalialan edustajat eivät pitäneet motivoituneisuutta lukuun ottamatta pehmeitä taitoja ensisijaisina taitoina (painoarvot vaihtelevat välillä $4.7-5.4$ ), mitä vastoin terveysalan ja sosiaali- ja terveysalan edustajat painottivat niitä heittäytymistä ja irrottelevaa työnotetta lukuun ottamatta kohtuullisen korkealle (painoarvot vaihtelevat välillä $(5.4-6.0)$.

K oska erot ryhmien välillä ovat systemaattisia, voidaan eroa selittää kahdella tavalla: yhtäältä kyse voi olla siitä, että ryhmien vastaustekniikoissa on ollut eroja. Tällöin sosiaalialan edustajat ovat välttäneet äärinumeroiden antamista, mikä heijastuu systemaattisesti matalampana keskiarvona. Toisaalta kyse voi olla siitä, että sosiaalialan toiminnassa pehmeillä kvalifikaatioilla ei ole niin suurta merkitystä kuin terveysalan todellisuudessa. Selitysmalleista itse kallistuisin ensimmäisen vaihtoehdon kannalle, sillä on vaikea kuvitella, miksi sosiaalialan työssä ei aidosti tarvittaisi pehmeää osaamista. Samaan hengenvetoon on kuitenkin todettava, että esimerkiksi Ulla Mutka on sosiaalityön muutoksia pohtiessaan (Mutka 1998, 12) todennut, että sosiaalialan työn todellisuus on oleellisesti monimutkaistunut aiemmasta. Tämä saattaisi selittää sen, että selvitäkseen monimutkaisesta ja ristiriitaisesta "taistelutantereesta" on parempi painottaa enemmänkin teknistä osaamista kuin ns. pehmeää suhtautumista työhön ja asiakkaisiin. Haastattelukierroksen yhteydessä niin terveysalan kuin sosiaalialankin edustajat perustelivat pehmeän osaamisen samoilla argumenteilla tärkeäksi taidoksi.

Y hteenvetona voidaan todeta, että valtaosin mittarissa mukana olleet pehmeän osaamisen osatekijät edustavat perusosaamista. Aitoa tulevaisuuden osaamista ei joukossa ollut. Sosiaalialan edustajat painottivat näitä taitoja vähemmän kuin terveysalan ja sosiaali- ja terveysalan edustajat. Lukuun ottamatta heittäytymistä ja irrottelevaa työnotetta pehmeät osaamistarpeet saivat korkean painoarvon.

\section{POHDINTAA}

Erityisesti ammatillisen koulutuksen tulisi pystyä uudistumaan muuttuvien työn sisältöjen ja vaatimusten mukana (Väärälä 1993, 22, 1995b, 72-76). Ammatillisen koulutuksen sisällön ennustaminen saattaa kuitenkin olla vaikeaa, sillä sosiaali- ja terveysalalla yhteiskunnallinen kehitys määrittää pitkälti sen, millaista sosiaalipalvelua ja terveyspalvelua voidaan tarjota. Toisaalta Mutkan mukaan $(1998,12)$ sosiaalialan työ on itsessään muuttunut ristipaineiseksi, eri suuntiin vaikuttavien voimien ja toisilleen vastakkaisten intressien temmellyskentäksi. Samanaikaisesti tiedämme, että ihmisten fysiologiset perustarpeet eivät välttämättä ole juurikaan muuttuneet vuosituhansien varrella. Yhtälailla avuttomana yksilö maailmaan tulee kuin ennenkin. Maailma kuitenkin muuttuu ja koulutuksen olisi kyettävä muuttumaan sen myötä ellei peräti ennakoimaan maailman muuttumista.

E räs tulevaisuuden haaste koulutukselle on se, kuinka tietää ne asiat, joita sosiaali- ja terveydenhuollon ammattilaiset tarvitsevat tulevaisuudessa. Kun tämä saadaan selville (vai saadaanko?), herää uusi kysymys: kuinka mainittuja asioita voidaan opettaa, vai voidaanko niitä ylipäänsä opettaa? Kivinen $(1998,79)$ suhtautuu skeptisesti ajatukseen, että työtä koskeva tieto voitaisiin siirtää opetuksen sisällöksi. Jos pitää paikkansa Turtiaisen huomio siitä, että tekijältä vaaditaan yhä enemmän persoonallisia piirteitä tai henkilökohtaisia ominaisuuksia, tämä asettaa uudenlaisia paineita aikuiskoulutukselle: pystytäänkö oma-aloitteisuutta, rehellisyyttä, kiinnostusta alaan tai tunnollisuutta opettamaan (ks. Turtiainen 1997, 23)? Jos Peltosen (1993, 145) esittämät "henkiinjäämisperiaatteet" pätevät, pitäisikö opiskelijoille opettaa oppimiskykyä, luovuutta, joustavuutta ja ydinasioihin keskittymistä. Toisaalta Mäkinen kuitenkin $(1998,90)$ torjuu ajatuksen siitä, että olisi erillisiä kursseja kommunikaatiotaidoista, yhteistyövalmiuksista 
tai innovatiivisuudesta. Tämä herättää kysymyksen, pitäisikö jo alalle pyrkivällä olla näitä ominaisuuksia, joita vain jalostetaan koulutuksen aikana. Mikäli näin on, tämän pitäisi heijastua koulun sisäänottokriteereihin ja pääsyvaatimuksiin. Samalla voidaan kuitenkin kysyä, missä vaiheessa yksilön kehitystä mainitut ominaisuudet tai taidot kehittyvät. Olisi liioiteltua sanoa, etteikö yksilö muuttuisi koulutuksen ja kokemusten kautta. Ehkä kiintoisa jatkotutkimuksen kohde saattaisikin olla se, mitkä yleiskvalifikaatioista ovat opittavissa aikuiskoulutuksessa ja toisaalta kuinka niitä voitaisiin tehokkaimmin opettaa sen aikana.

Y ksi mahdollisuus arvioida yleistä soveltuvuutta ihmistyöhön - erityisesti sosiaali- ja terveysalalle - olisi pohtia pehmeän osaamisen osuutta hyvän työntekijän ja ammattilaisen kvalifikaatioissa. Itse nostaisin pehmeän osaamisen esille eräänä mahdollisuutena arvioida ammattilaisen (tai koulutukseen pyrkivän) lahjakkuutta ihmistyöhön. Pehmeä osaaminen - emotionaalinen herkkyys havaita tilanteita, eräänlainen intra- ja interpersoonallinen lahjakkuus (Gardner 1993), intuition käyttö, innostuminen ja innostaminen - ovat hieman selkiytymätön tai julkituomaton osa ammattitaitoa, mutta itse näkisin ne tekijöinä, jotka erottavat hyvän ammattilaisen vieläkin paremmasta. Huippuammattilaiselta vaaditaan raudanlujaa ammattitaitoa, motivaatiotekijöitä, työhön sopeutumista, sosio-kulttuurisia taitoja ja innovatiivisuutta. Jos näiden lisäksi ammattilaisella on ominaisuuksia, joita olen nimittänyt pehmeiksi taidoiksi, ammattilainen ei ole omassa ammattimaisuudessaan luotaantyöntävän hyvä, vaan aidosti - tietoisesti tai tietämättään - saa muutkin kollegansa ja asiakkaansa innostumaan ja antamaan enemmän, kuin mitä ilman tätä loistavaa ammattilaista tapahtuisi.

\section{Lähteet}

ELLÄ, H. (1998) Koulutus työympäristön uusien osaamisvaatimusten - siirtotaitojen ja joustavuuden tuottajana. Futura 3/1998, 38-45.

GARDNER, H. (1993) Frames of Mind. The Theory of Multiple Intelligences. Basic Books, New York.
HALTiA, P. \& Kivinen, K. (1995) Ammattien tutkiminen ja ammattitutkinnot. Opetushallitus ja Koulutussosiologian tutkimuskeskus, Turun yliopisto.

HAUTAMÄKI, A. (toim.1996) Suomi teollisen ja tietoyhteiskunnan murroksessa. SITRA 154. Helsinki.

HELAKORPI, S. (1995) Ammattitaito ja sen arviointi. Teoksessa Turpeinen, R. (toim.) 1995: Ammattitutkintojen ja näyttökokeiden teoreettisia perusteita. Helsinki, Opetushallitus. 63-86.

HONKAKOSKI, A. (1995) Sosiaalialan toiminnan todellisuus, ammattitaito ja koulutus. Opetushallitus. Kehittyvä koulutus 1/1997. Hakapaino, Helsinki.

IHANAINEN, P. (1995) Tunteet ammattitaidon perustana. Teoksessa Turpeinen, R. (toim.) 1995: Ammattitutkintojen ja näyttökokeiden teoreettisia perusteita. Helsinki, Opetushallitus. 87-97.

JAAKKOLA, R. (1995) Työelämän ja koulutuksen käsitteistöstä. Teoksessa Turpeinen, R. (toim.) 1995: Ammattitutkintojen ja näyttökokeiden teoreettisia perusteita. Helsinki, Opetushallitus. 113-127.

KAIVO-OJA, J. (1998) Tietoyhteiskunnan työmarkkinakehityksen tulevaisuusarvio 2017 -tutkimus. Osaamistarpeet kommunikaatio-klusterissa. Esitys ESR-ennakoinnin parhaita käytäntöjä ja tuloksia seminaarissa 20.3.1998.

KIVINEN, K. (1991) Työn vaativuuden arviointi ja naisten työt. Tehy, Kouvolan painotalo.

KIVINEN, K. (1994) "Orjat ja sankarit": sosiaali- ja terveydenhuollon muuttuvat työt ja kvalifikaatiovaatimukset. Sosiaali- ja terveydenhuollon työn ja koulutuksen kehittämisprojekti. Sarja A, Tutkimusraportteja 1/1994.

KIVINEN, K. (1998) Äänetön ammattitaito pätevyyden osatekijänä. Teoksessa Räisänen A. (toim.) 1998: Hallitaanko Ammatti? Pätevyyden määrittelyä arvioinnin perustaksi. Opetushallitus, Arviointi 2/1998, 72-82. Yliopistopaino, Helsinki.

KIVINEN, O., Rinne R., Kankaanpää, A., Haltia, P. \& Ahola, S. (1993) Ammatti, koulutus ja kvalifikaatiot. Koulutussosiologian tutkimuskeskus. Rapotteja 17. Turun yliopisto.

KORHONEN, K. (1998) DI -koulutuksen haasteet tietoyhteiskunnassa. Futura 1/1998, 74-78.

KUUSI, O. (1993) Delfoi-tekniikka tulevaisuuden tekemisen välineenä. Teoksessa Vapaavuori, M. (toim.) 1993: Miten tutkimme tulevaisuutta? Tulevaisuuden tutkimuksen seura, Acta Futura Fennica no 5. Painatuskeskus, Helsinki. 132-140.

KUUSI, O. (1996) Tulevaisuuden avainosaaminen. Futura 4/1996, 80-90.

LINSTONE, H.A. \& Turoff, M. (Eds. 1975) The Delphi Method: Techniques and Applications. AddisonWesley, Massachusetts.

MANNERMAA, M. (1996) Tulevaisuudentutkimus ja ennustaminen. SoTeKeKo-tied ote 1/1996, 9-13.

METSÄMUURONEN J. (1997) Delfi -tekniikka sosiaalija terveydenhuollon tulevaisuuden osaamistarpeiden tutkimisessa. Futura 2/1997, 27-30.

METSÄMUURONEN, J. (1998) Maailma muuttuu miten muuttuu sosiaali- ja terveysala? STM, Opetushallitus, Stakes, Suomen Kuntaliitto. Työministeriön ESR-julkaisusarja 39/98. Edita, Helsinki.

MUTKA, U. (1998) Sosiaalityön neljäs käänne. Asiantuntijuuden mahdollisuudet vahvan hyvinvointivaltion jälkeen. SoPhi, Jyväskylän yliopisto. Jyväs- 
kylän yliopistopaino, Jyväskylä.

MÄKELÄ, K. (1995) Kvalifikaatioanalyysi - miksi ja miten? Aikuiskasvatus 2/1995. 128-131

MÄKINEN, R. (1998) Ammattipätevyyden arviointi ammattitutkintoja varten. Teoksessa Räisänen A. (toim.) 1998: Hallitaanko Ammatti? Pätevyyden määrittelyä arvioinnin perustaksi. Opetushallitus, Arviointi 2/1998, 83-92. Yliopistopaino, Helsinki.

OlluS, M., Rovio, R., Mieskonen, J., Vuorinen, P., Karko, J., Vuori, S. \& Yli-Anttila (1990) Joustava tuotanto ja verkostotalous. Tekniikan, talouden ja yhteiskunnan vuorovaikutus 1990-luvulla. Sitran julkaisuja 109 . Helsinki.

PELTONEN, M. (1993) Työn, ammatin ja opiskelun kehityslinjoja. Futura 3/1993, 143-147

PELTTARI, P. (1997) Sairaanhoitajan työn nykyiset ja tulevaisuuden kvalifikaatiovaatimukset. Stakes, Tutkimuksia 80. Gummerus, Jyväskylä.

PELTTARI, P. (1998a) Hoitotyön ammattitaitovaatimukset tulevaisuudessa. Futura 1/98, 71-73.

PELTTARI, P. (1998b) Kvalifikaatio vai kvalifikaatiovaatimus? Futura 1/98, 86-94

RÄISÄNEN A. (1998) Ammatillisen osaamisen arviointi. Teoksessa Räisänen A. (toim.) 1998: Hallitaanko Ammatti? Pätevyyden määrittelyä arvioinnin perustaksi. Opetushallitus, Arviointi 2/1998, 920. Yliopistopaino, Helsinki.

SCHIENSTOCK, G. \& Koski, P. (1997) What overall qualifications will be needed in future? Futura 1/ 1997, 64-68

TAALAS, M. (1993) Ammattitaidon ja sen arvioinnin tarkastelunäkökulma. Teoksessa Mäkinen, R. \& Taalas, M. (toim.) 1993: Producing and certifying vocational qualifications. Kasvatustieteiden tutkimuslaitoksen julkaisusarja B. Teoriaa ja käytäntöä 83. 169-176.

TAALAS, M. (1995a) Ammattitutkinto ammattitaidon näyttönä. Ammatillisen aikuistutkintojen kehittäminen. Kasvatustieteiden tutkimuslaitoksen julkaisusarja A. Tutkimuksia 62 .

TAALAS, M. (1995b) Ammattitaito ja näyttökokeet.
Teoksessa Turpeinen, R. (toim.) 1995: Ammattitutkintojen ja näyttökokeiden teoreettisia perusteita. Helsinki, Opetushallitus. 99-112.

TOIKKA, K. (1984) Kehittävä kvalifikaatiotutkimus. Valtion koulutuskeskuksen julkaisusarja B 25. Helsinki.

TUROFF M. \& Hiltz, S.R. (1996) Computer-Based Delphi Processes. Teoksessa Adler, M. \& Ziglio, E. (toim.) 1996: Gazing into the Oracle. The Delphi Method and its Application to Social Policy and Public Health. 56-85.

TURTIAINEN, J. (1997) Kvalifikaatio ja ennakointi. Työpolittinen aikakauskirja. 1-2/1997, 15-34.

WILLIAMS, P.L. \& Webb, C. (1994) The Delphi technique: a methodological discussion. Journal of Advanced Nursing 19, 180-186.

VUORINEN P. (1988) Työn ja ammattien muutos. Teoksessa Opetussuunnitelman laatiminen ammatillisessa oppilaitoksessa. Helsinki, Kaupunkiliitto.

VÄÄRÄLÄ, R. (1993) Ammatin opettamisen murros. Teoksessa Salminen, H. (toim.) Haasteita sosiaali- ja terveydenhuollon koulutukselle. Opetushallitus. Yliopistopaino, Helsinki. 13-23.

VÄÄRÄLÄ, R. (1995a) Ammattikoulutus ja kvalifikaatiot. Acta Univrsitatis Lappoensis 9. Rovaniemi: Lapin yliopisto

VÄÄRÄLÄ, R. (1995b) Ammattikoulutus muuttuvilla työmarkkinoilla. Opetushallitus, Tutkimus 4/ 1995, Yliopistopaino, Helsinki.

VÄÄRÄLÄ, R. (1996) Työhön vai ammattiin - koulutuksen pulmat 2000-luvulle. SoTeKeKo- tiedote 1/1996.

VÄÄRÄLÄ, R. (1998) Pätevyys ja ammatillinen muutos. Teoksessa Räisänen A. (toim.) 1998: Hallitaanko Ammatti? Pätevyyden määrittelyä arvioinnin perustaksi. Opetushallitus, Arviointi 2/ 1998, 21-34

Artikkeli saapui toimitukseen 12.9.1998. Se hyväksyttiin julkaistavaksi 25.3.1999. 